\title{
Doxycycline attenuates breast cancer related inflammation by decreasing plasma lysophosphatidate concentrations and inhibiting NF-KB activation
}

\author{
Xiaoyun Tang ${ }^{1}$, Xianyan Wang ${ }^{1}$, Yuan Y. Zhao ${ }^{2}$, Jonathan M. Curtis ${ }^{2}$ and David N. Brindley ${ }^{1,3^{*}}$
}

\begin{abstract}
Background: We previously discovered that tetracyclines increase the expression of lipid phosphate phosphatases at the surface of cells. These enzymes degrade circulating lysophosphatidate and therefore doxycycline increases the turnover of plasma lysophosphatidate and decreases its concentration. Extracellular lysophosphatidate signals through six G protein-coupled receptors and it is a potent promoter of tumor growth, metastasis and chemo-resistance. These effects depend partly on the stimulation of inflammation that lysophosphatidate produces.

Methods: In this work, we used a syngeneic orthotopic mouse model of breast cancer to determine the impact of doxycycline on circulating lysophosphatidate concentrations and tumor growth. Cytokine/chemokine concentrations in tumor tissue and plasma were measured by multiplexing laser bead technology. Leukocyte infiltration in tumors was analyzed by immunohistochemistry. The expression of IL-6 in breast cancer cell lines was determined by RT-PCR. Cell growth was measured in Matrige ${ }^{\mathrm{TM}}$ 3D culture. The effects of doxycycline on NF-kB-dependent signaling were analyzed by Western blotting.
\end{abstract}

Results: Doxycycline decreased plasma lysophosphatidate concentrations, delayed tumor growth and decreased the concentrations of several cytokines/chemokines (IL-1ß, IL-6, IL-9, CCL2, CCL11, CXCL1, CXCL2, CXCL9, G-CSF, LIF, VEGF) in the tumor. These results were compatible with the effects of doxycycline in decreasing the numbers of $\mathrm{F} 4 / 80^{+}$macrophages and $\mathrm{CD} 31^{+}$blood vessel endothelial cells in the tumor. Doxycycline also decreased the lysophosphatidate-induced growth of breast cancer cells in three-dimensional culture. Lysophosphatidateinduced Ki-67 expression was inhibited by doxycycline. NF-KB activity in HEK293 cells transiently expressing a NFKB-luciferase reporter vectors was also inhibited by doxycycline. Treatment of breast cancer cells with doxycycline also decreased the translocation of NF-KB to the nucleus and the mRNA levels for IL-6 in the presence or absence of lysophosphatidate.

Conclusion: These results contribute a new dimension for understanding the anti-inflammatory effects of tetracyclines, which make them potential candidates for adjuvant therapy of cancers and other inflammatory diseases.

Keywords: Autotaxin, Inflammatory cyotokines, Tetracyclines, Peripheral blood mononuclear cells, Macrophage infiltration

\footnotetext{
* Correspondence: david.brindley@ualberta.ca

'Department of Biochemistry, Signal Transduction Research Group, University

of Alberta, Edmonton, AB T6G 2S2, Canada

${ }^{3}$ Department of Biochemistry, 357 Heritage Medical Research Centre,

University of Alberta, Edmonton, AB T6G 2S2, Canada

Full list of author information is available at the end of the article
} 


\section{Background}

Chronic inflammation is one of the intrinsic features of the tumor microenvironment, which makes it an important hallmark of cancer development and progression [1-3]. Autotaxin (ATX) is a secreted enzyme, which is a key regulator of inflammation through its production of lysophosphatidate (LPA) from lysophosphatidylcholine [4, 5]. LPA signals through six $G$ protein-coupled receptors to stimulate cell proliferation, survival, migration and angiogenesis, which promote tumor growth $[4,6]$. Increased ATX and LPA levels are also important in the development of chronic inflammation in asthma, pulmonary fibrosis, rheumatoid arthritis, atherosclerosis, hepatitis, multiple sclerosis, Crohn's disease and ulcerative colitis [7-9].

Increased LPA signaling is closely associated with tumor growth and cancer-related inflammation [10-13]. This is because LPA induces the expression of inflammatory cytokines through activating nuclear factor- $\mathrm{kB}(\mathrm{NF}-\mathrm{kB})$ $[14,15]$. We reported that inflammatory cytokines from breast tumors stimulate ATX production by adjacent adipose tissue [11]. The consequently high LPA concentration enhances lymphocyte infiltration, which increases the inflammatory status in the tumor. This vicious cycle of LPA signaling increases the production of inflammatory mediators, which further increases tumor growth, metastasis and the development of chemo-resistance $[10,11,16]$. Cancer-related inflammation comprises a complicated crosstalk between cancer cells and leukocytes. The massive infiltration of tumor associated macrophages (TAM), especially M2 macrophages, represents a poor prognosis in many types of cancer [17-19]. In the tumor microenvironment, TAMs originate from the monocyte lineage through the action of cytokines, e.g., chemokine (C-C motif) ligand 2 (CCL2), secreted by stromal cells and cancer cells [20,21]. TAMs stimulate cancer cell proliferation by secreting growth factors, e.g., epidermal growth factor (EGF) [22] and platelet derived growth factor (PDGF) [23]. TAMs also promote angiogenesis by producing vascular endothelial growth factor (VEGF) [24] and suppress antitumor immunity by secreting immune regulatory molecules such as IL-10 [25] and transform growth factor $\beta$ (TGF $\beta$ ) [26].

Treatment of mice that had breast cancer with a specific ATX inhibitor, ONO-8430506, had an anti-inflammatory effect. It decreased LPA level in plasma and tumors, thereby decreasing the concentrations of 20 inflammatory cytokines/chemokines in adipose tissue adjacent to the tumor [10, 27]. An alternative way to regulate LPA levels is through a family of enzymes named lipid phosphate phosphatases (LPPs), which consists of three isoforms, LPP1, LPP2 and LPP3 [28, 29]. LPPs dephosphorylate extra-cellular LPA to monoacylglycerol, which terminates
LPA signaling. The expressions of LPP1 and LPP3 are decreased in many cancers, including breast cancer $[28,30]$. We recently discovered that tetracyclines increase extracellular LPA degradation by enhancing the stabilities of LPP1, LPP2 and LPP3 in several breast cancer cell lines and in non-transformed cells [31]. The clearance of LPA from the circulation in rats was accelerated by doxycycline treatment and LPA concentrations in mouse plasma were decreased [31]. This tetracycline effect does not involve the inhibition of matrix metalloproteinase activity [31].

Tetracyclines also show anti-inflammatory effects, and their clinical use has been expanded from microbial infection to inflammatory diseases including acne [32], rosacea [33], perioral dermatitis [34] and gingivitis [35]. Effective use of tetracyclines has been reported in rheumatoid arthritis [36], osteoarthritic cartilage [37], allergen-induced inflammation and inflammatory skin disorders [38].

Therefore, the effects of tetracyclines on LPA degradation and inflammation suggest that they may have beneficial effects on cancer therapy. In the present study, we demonstrated that doxycycline decreased breast tumor growth in a syngeneic orthotopic mouse model. Doxycycline treatment decreased plasma LPA levels and the concentrations of several inflammatory mediators, the infiltration of $\mathrm{F} 4 / 80^{+}$macrophages and blood vessel formation in the tumor. Doxycycline also inhibited NF$\mathrm{KB}$ activation in breast cancer cells by decreasing phosphorylation of the inhibitor of $\kappa \mathrm{B}(\mathrm{I} \kappa \mathrm{B})$ and nuclear translocation of NF- $\mathrm{B}$. These results demonstrate that doxycycline has a novel action in decreasing LPA signaling, which contributes to its anti-inflammatory effects. These actions provide new mechanisms that support the use of tetracyclines as an adjuvant therapy for cancers and other inflammatory diseases.

\section{Results}

Doxycycline delayed tumor growth and decreased the numbers of tumor-associated macrophages and blood vessels in a syngeneic orthotopic mouse model of breast cancer

We recently discovered that doxycycline increased the dephosphorylation of extracellular LPA in MDA-MB231, MCF-7 and 4T1 breast cancer cells by increasing the expression of the LPPs on the cell surface [31]. This explained why animals treated with doxycycline showed increased clearance of LPA from the circulation and decreased plasma LPA levels. These results indicate that doxycycline could have favorable effects on cancer treatment, since LPA signaling is up-regulated in many cancers.

We, therefore, used a syngeneic mouse model of breast cancer to study the effects of doxycycline on tumor growth. Doxycycline at $50 \mathrm{mg} / \mathrm{kg} /$ day was tolerated fairly 
well and it resulted in a loss of body weight of only $\sim 10 \%$ after 15 days. Doxycycline treatment significantly decreased tumor volume by $\sim 25 \%$ and tumor weight by $\sim 35 \%$. (Fig. 1a, b). There was also a significant decrease in tumor weight in the doxycycline-treated group of $\sim 20 \%$ when it was expressed relative to body weight (Additional file 1: Figure S1A). The inhibitory effect of doxycycline on tumor growth was maintained for 24 days after inoculation (Additional file 1: Figure S1B). The apparent decrease in the number of metastatic nodules on lung surface 24 days after inoculation in doxycycline-treated mice did not reach the level of statistical significance (Additional file 1: Figure S1C). As predicted, doxycycline treatment decreased plasma LPA concentrations by $\sim 26 \%$ (Fig. 1d), which can be explained by the doxycycline-induced increase of LPP activity on the cells surface [31]. ATX activity in plasma was not affected significantly by doxycycline (Fig. 1e).

Immunohistochemistry staining of the breast tumors demonstrated that doxycycline treatment significantly decreased the numbers of $\mathrm{F} 4 / 80^{+}$macrophages by $50 \%$ and $\mathrm{CD} 31^{+}$blood vessels in the tumor by $\sim 30 \%$ (Fig. 1f, $\mathrm{g}$ and $\mathrm{h})$. There was no significant change in infiltration of total $\mathrm{CD} 45^{+}$leukocytes, $\mathrm{CD} 8^{+}$cytotoxic $\mathrm{T}$ cells and Foxp $^{+}$regulatory T cells (Additional file 1: Figure S1D).
A

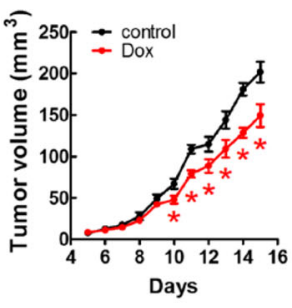

B

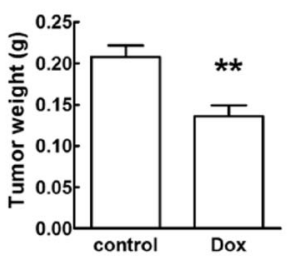

$\mathbf{F}$

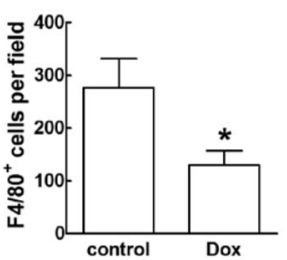

G

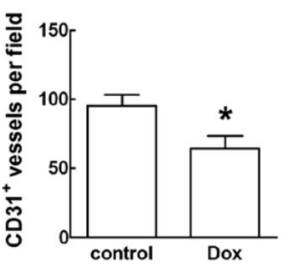

\section{C}

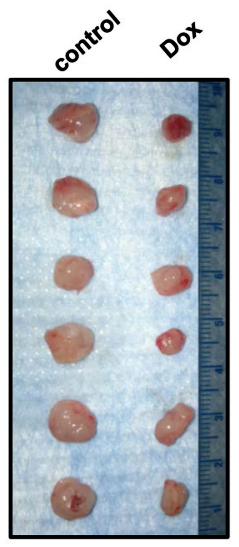

H

$\mathbf{F} 4 / 80$

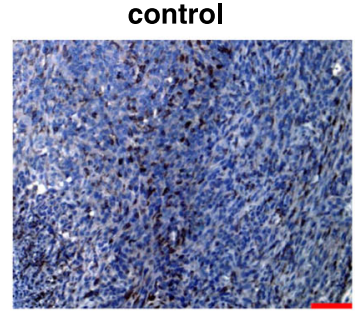

CD31

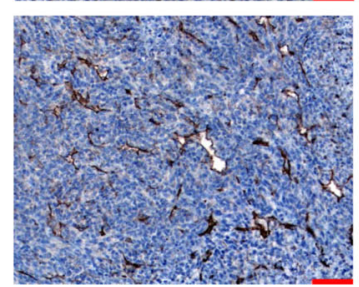

D

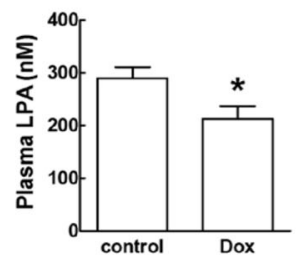

$\mathbf{E}$

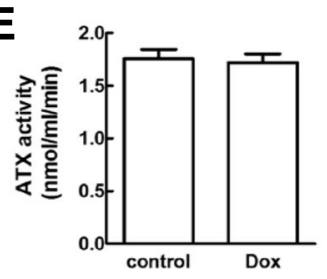

Dox
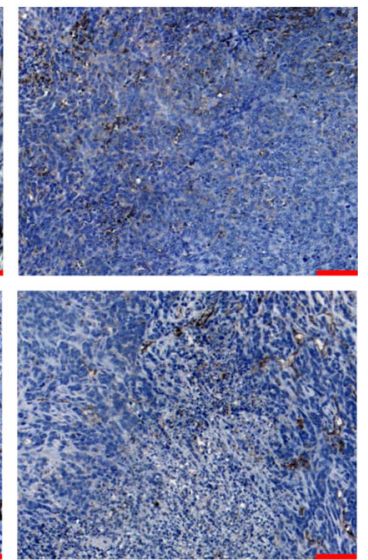

Fig. 1 Doxycycline delayed breast tumor growth, decreased plasma LPA concentration, inhibited F4/80+ macrophage infiltration and blood vessel formation in the tumor. a. Tumor volume from day 5 to day 15 post inoculation of $4 T 1$ cells. BALB/c mice were treated with doxycycline (Dox) at $50 \mathrm{mg} / \mathrm{kg} /$ day by i.p. injection. Control mice were given saline by i.p. injection. $n=6$ for each group, ${ }^{*} p<0.05$ relative to control. b. The difference in tumor weight. $n=6$ for each group, ${ }^{* *} p<0.01$ relative to control. c. Image of the tumors from control and Dox treated mice. d. Plasma LPA concentration of the mice with tumor. $n=6$ for each group, ${ }^{*} p<0.05$ relative to control. e. Plasma autotoxin (ATX) activity of control and Dox treated mice. f. $\mathrm{F} 4 / 80^{+}$macrophage numbers per field detected by IHC in tumors from control and Dox treated mice. ${ }^{*} p<0.05$ relative to control. g. CD31 ${ }^{+}$blood vessel numbers per field detected by IHC in tumors from control and Dox treated mice. ${ }^{*} p<0.05$ relative to control. These were quantified by examining 5 different fields from each tumor and by using 6 mice per group. $\mathbf{h}$. Representative images of IHC staining for $\mathrm{F} 4 / 80^{+}$macrophages and $\mathrm{CD} 31^{+}$blood vessels in tumors from control and Dox treated mice. Scale bar $=100 \mu \mathrm{m}$. Results are means \pm SEM. Results were analyzed by a Student's $t$-test 


\section{Doxycycline decreased inflammatory cytokine levels in} plasma and tumor tissue

Since LPA is an important mediator of inflammation, we next determined the levels of cytokines in the breast tumor. Doxycycline treatment significantly decreased the concentrations of IL-1 $\beta$, IL-6, IL-9, CXCL1, CXCL2, CXCL9, CCL2, CCL11, G-CSF, LIF, and VEGF in the tumor (Fig. 2). In addition, we measured the concentrations of G-CSF, IL-
$1 \beta$, IL-6, CCL4 and TNF $\alpha$ in the plasma of the mice with breast cancer. Only G-CSF was decreased significantly by doxycycline treatment (Additional file 2: Figure S2).

\section{Doxycycline decreased IL-6, CCL2 and CXCL2 expression} in $4 \mathrm{~T} 1$ cells

Tumors are composed of cancer and stromal cells, all of which express cytokines. Our previous work

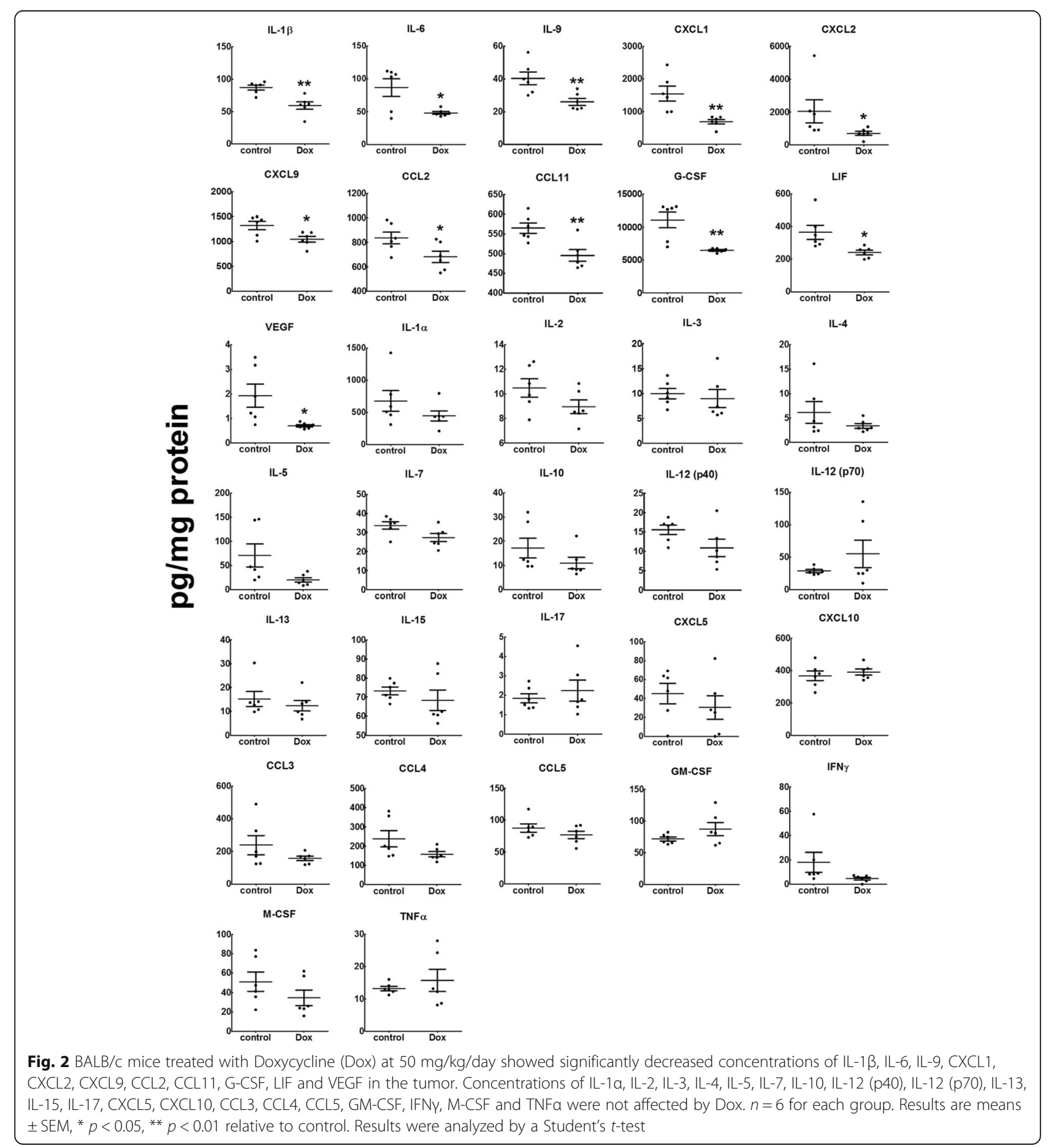


showed that LPA stimulated inflammatory cytokine secretion by mouse $4 \mathrm{~T} 1$ breast cancer cells [11]. Doxycycline decreased plasma LPA [31], which could cause lower cytokine production by cancer cells. In present study, LPA induced a rapid increase of IL-6 mRNA expression, which reached a peak at $1 \mathrm{~h}$ after stimulation of 4T1 cells. Doxycycline treatment decreased IL-6 expression, even when LPA was absent (Fig. 3a). This indicated that the inhibition of IL-6 expression by doxycycline was not entirely through suppressing LPA signaling. Therefore, we used TNF $\alpha$ as an agonist and doxycycline also inhibited TNF $\alpha-$ induced IL-6 expression (Fig. 3b). Similar results were observed in human MDA-MB-231 cells, in which doxycycline decreased the expressions of IL-6 in the presence or absence of LPA or TNF $\alpha$ (Fig. 3c and $\mathrm{d}$ ). We also showed that doxycycline decreased the secretions of IL-6, CCL2 and CXCL2 by $4 \mathrm{~T} 1$ cells and this did not depend on the presence of LPA (Fig. 4).
Doxycycline decreased NF-KB translocation and IKB phosphorylation in breast cancer cells

Inflammatory signals from both LPA and TNF $\alpha$ receptors can converge on NF- $\mathrm{kB}$, which increases the expression of inflammatory cytokines, e.g., IL-6. We predicted that doxycycline decreases inflammatory cytokine expression by inhibiting NF- $\mathrm{kB}$-mediated transcription. As expected, LPA and TNF $\alpha$ increased the translocation of NF- $\mathrm{kB}$ to the nucleus in $4 \mathrm{~T} 1$ cells. These effects were inhibited by doxycycline (Fig. $5 \mathrm{a}$ and b). Doxycycline also inhibited TNF $\alpha$-induced translocation of NF- $\mathrm{KB}$ to the nucleus in MDA-MB-231 cells (Fig. 5c). In agreement with this, IкB phosphorylation and the degradation of total I $\mathrm{B}$ induced by TNF $\alpha$ were decreased by doxycycline (Fig. 5d). Doxycycline decreased both the basal and TNFo-induced ratio of luminescence in HEK293 cells transiently transfected with NF-kB luciferase reporter and Renilla luciferase vectors (Additional file 3: Figure S3). Therefore, the anti-inflammation effect of doxycycline involves decreases in NF-кB-induced transcription.
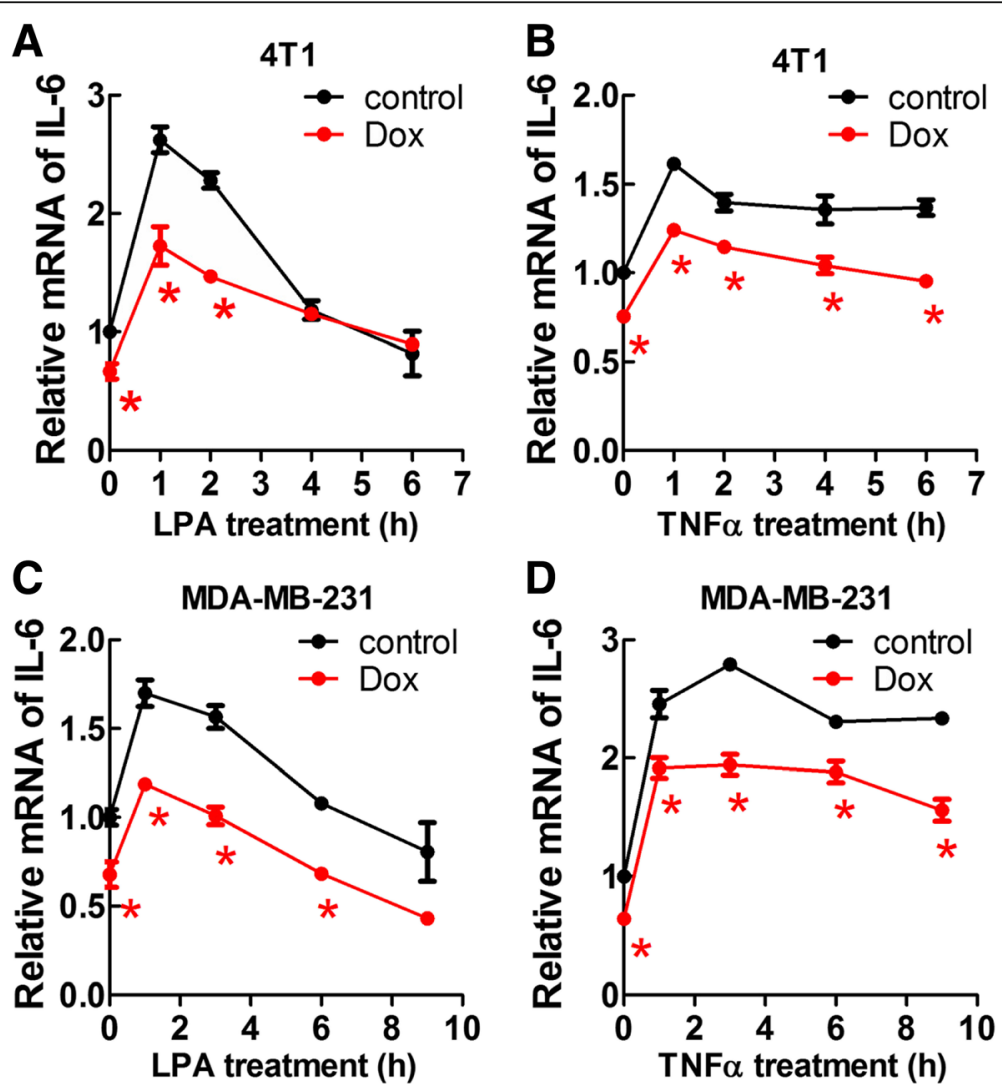

Fig. 3 Doxycycline (Dox) significantly decreased LPA and TNFa induced IL-6 mRNA expression in breast cancer cells. Cells were serum starved for $14 \mathrm{~h}$ in DMEM/0.1\% BSA and then followed with LPA $(1 \mu \mathrm{M})$ or TNFa $(20 \mathrm{ng} / \mathrm{ml})$ stimulation. For Dox-treated cells, $5 \mu \mathrm{g} / \mathrm{ml}$ of Dox was included during serum starvation and stimulation. $\mathbf{a}$. Time course of LPA induced IL-6 expression in 4T1 cells and the inhibition by Dox. $\mathbf{b}$. Time course of TNFa induced IL-6 expression in 4T1 cells and the inhibition by Dox. c. Time course of LPA induced IL-6 expression in MDA-MB-231 cells and the inhibition by Dox. $\mathbf{d}$. Time course of TNFa induced IL-6 expression in MDA-MB-231 cells and the inhibition by Dox. * $p<0.05$ relative to control. Results are means \pm SEM from three independent experiments. Results were analyzed by ANOVA with an SNK posthoc test 


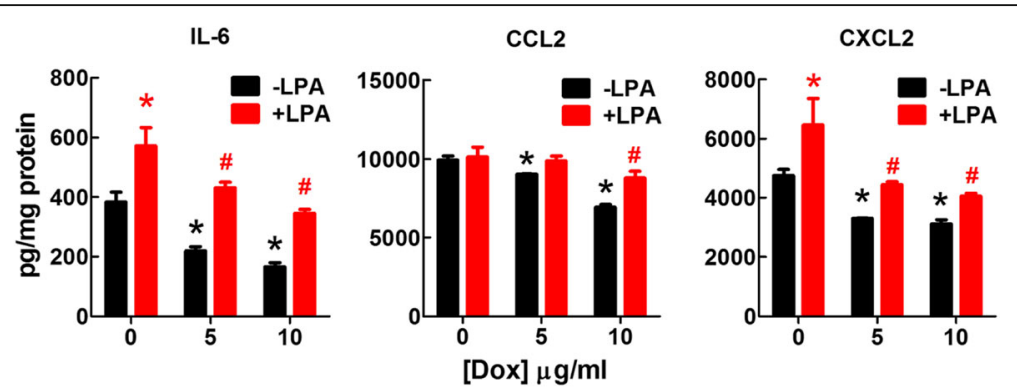

Fig. 4 Doxycycline (Dox) significantly decreased the secretion of IL-6, CCL2 and CXCL2 by $4 \mathrm{~T} 1$ cells. Cells were cultured with DMEM/10\% FBS. The medium was changed with DMEM/0.1\% BSA with or without LPA $(5 \mu \mathrm{M})$ and Dox $(5 \mu \mathrm{g} / \mathrm{ml}$ or $10 \mu \mathrm{g} / \mathrm{ml})$. Conditioned medium was collected after incubation for another $24 \mathrm{~h}$. Measurements were normalized to the cell protein. ${ }^{*} p<0.05$ relative to cells without Dox and LPA treatment, $\# p<0.05$ relative to cells treated with LPA but not Dox. Results are means \pm SEM from three independent experiments. Results were analyzed by ANOVA with an SNK posthoc test

\section{Doxycycline inhibited migration of mouse peripheral blood mononuclear cells (PBMCs) and IKB phosphorylation in RAW264.7 cells}

The inhibition of macrophage infiltration in tumors observed in Fig. 1d and e could have been caused by the doxycycline-induced decrease in the concentrations of chemo-attractants in the tumor (Fig. 2). It is also possible that doxycycline could directly inhibit the activation of macrophages [39]. We showed that doxycycline significantly decreased the migration of mouse PBMCs that was induced by LPA or CCL2 (Fig. 6a). Induction of $\mathrm{I} \kappa \mathrm{B}$ phosphorylation and degradation by lipopolysaccharide (LPS) in RAW264.7 macrophage cells were suppressed by doxycycline (Fig. 6b, c, d).

\section{Doxycycline did not affect LPA signaling downstream of LPA receptor activation}

LPPs control signaling by two distinct mechanisms: 1) by decreasing extracellular LPA concentrations and 2) by degrading a lipid phosphate formed downstream of the activation of $G$ protein coupled receptors, including LPA receptors [40]. To determine how doxycycline inhibits LPA signaling, we used LPA to induce the phosphorylations of Akt and ERK in 4T1 cells. Doxycycline at $10 \mu \mathrm{g} / \mathrm{ml}$ did not affect the phosphorylations of Akt or ERK (Fig. 7a). Similarly, $\mathrm{Ca}^{2+}$-transients induced by $10 \mu \mathrm{M}$ of LPA were not changed by doxycycline in MDA-MB-231 cells (Fig. 7b).

Doxycycline does enhance LPA degradation outside of cells [31]. However, this is a relatively slow process, which would not be rapid enough to substantially decrease the availability of the 1 to $10 \mu \mathrm{M}$ LPA used in the transient stimulations in Fig. 7a, b. By contrast, doxycycline did inhibit the effect of LPA in stimulating the proliferation of 4T1 cells in 3-D culture over 9 days where there was sufficient time each day to degrade extracellular LPA. The dependency of the doxycycline effect on LPA was established since cell growth induced by charcoal treated FBS (FBSC), in which LPA was severely depleted, was not affected by doxycycline (Fig. 7c). In monolayer culture, doxycycline also inhibited Ki-67 expression stimulated by LPA in MDA-MB231 cells (Additional file 4: Figure S4). These results demonstrate that it is the doxycycline-induced expression of the LPPs on the cell surface [31], which decreases external LPA availability that is responsible for decreasing the LPA effects on cell growth.

\section{Discussion}

Our previous study demonstrated a novel action of tetracyclines in increasing the stability of the LPPs in cancer and non-transformed cells [31]. This increased the expressions of LPP1, LPP2 and LPP3 at the surface of cells, which increased the degradation of extracellular LPA and lowered circulating LPA concentrations in mice. Up-regulations of ATX, LPA receptors and LPA levels coupled with decreased expression of LPP1 and LPP3 are closely associated with the growth and metastasis of many cancers [5, 28, 40]. Therefore, we determined if this novel effect of tetracyclines on LPP expression could decrease breast tumor growth. We showed that doxycycline decreased plasma LPA levels and delayed tumor growth in a syngeneic mouse model of breast cancer. LPA is also one of the critical triggers of tumor-induced inflammation by inducing the production of inflammatory cytokines in breast cancer cells [11]. In agreement with this, the doxycycline-induced decrease in plasma LPA was accompanied by a decrease in the concentrations of several cyotkines/chemokines (IL-1 $\beta$, IL-6, IL-9, CCL2, CCL11, CXCL1, CXCL2, CXCL9, G-CSF, LIF, VEGF) in the tumor.

LPPs have two mechanisms for attenuating LPA signaling. First, LPPs on the plasma membrane degrade extracellular LPA, which decreases the amount of external LPA that can signal through its receptors [31]. Doxycycline specifically increases this ecto-activity of 

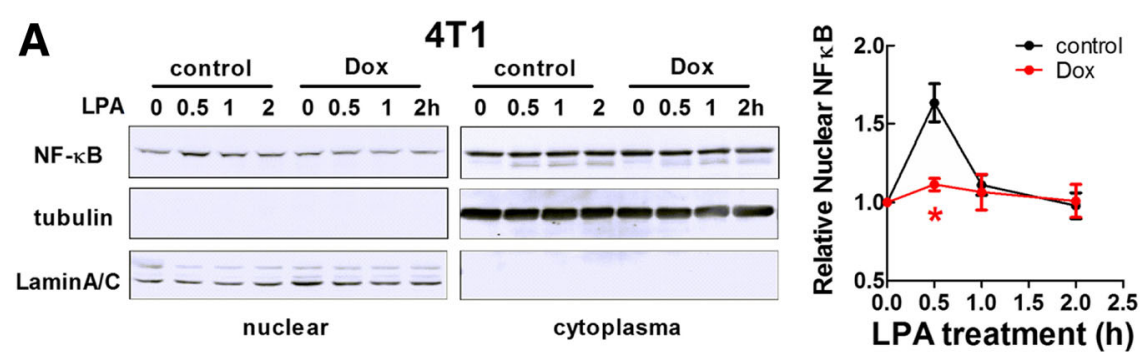

B

4T1
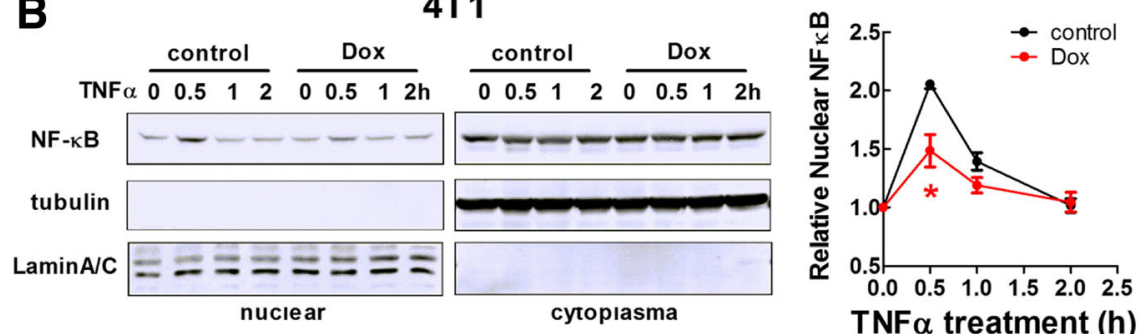

C

MDA-MB-231

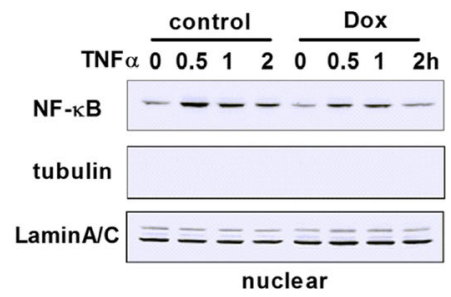

$\frac{\text { control }}{00.512} \frac{\text { Dox }}{0} 0.512 \mathrm{~h}$
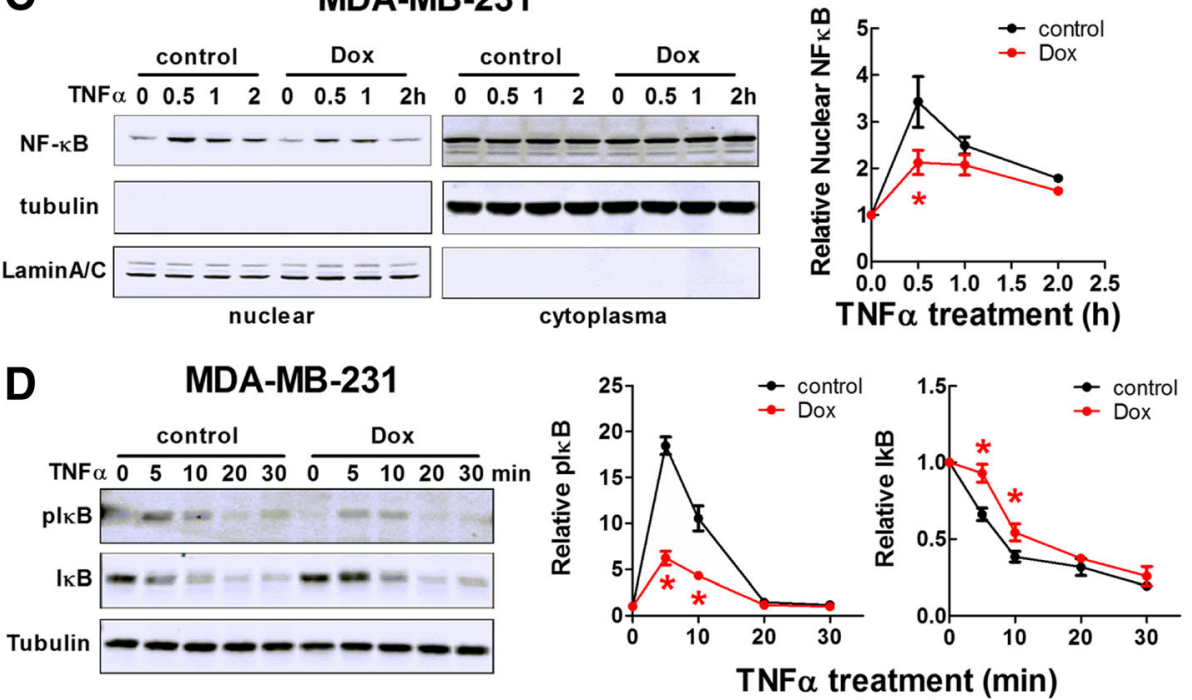

Fig. 5 Doxycycline (Dox) inhibited LPA and TNFa-induced translocation of NF-KB p65 to the nucleus in breast cancer cells. Cells were serum starved for $14 \mathrm{~h}$ in DMEM/0.1\% BSA and then followed stimulation with $5 \mu \mathrm{M}$ LPA or $20 \mathrm{ng} / \mathrm{ml}$ TNFa. For Dox-treated cells, $5 \mu \mathrm{g} / \mathrm{ml}$ of Dox was included during serum starvation and stimulation. $\mathbf{a}$. Time course of NF-KB translocation to nucleus induced by LPA in 4T1 cells and the effect of Dox. $\mathbf{b}$. Time course of NF-KB translocation to nucleus induced by TNFa in $4 \mathrm{~T} 1$ cells and the effect of Dox. $\mathbf{c}$. Time course of NF-KB translocation to nucleus induced by TNFa in MDA-MB-231 cells and the effect of Dox. $\mathbf{d}$. The effect of Dox on the time course of phospho-IkBa and total IkBa by TNFa in MDA-MB-231 cells. ${ }^{*} p<0.05$ relative to control. Results are means \pm SEM from three independent experiments. Results were analyzed by ANOVA with an SNK posthoc test

the LPPs, although it did not modify the rapid effects of LPA in activating $\mathrm{Ca}^{2+}$-transients, phosphorylations of ERK or Akt. This is explained since the ecto-LPP activity on plasma membranes would not have degraded sufficient LPA in our short-term experiments to attenuate rapid signaling. Doxycycline did, however, decrease the longer-term action of LPA in stimulating cell proliferation in 3D culture. The second mode of action of the LPPs is that increased expression of LPPs inside cells blocks cell signaling downstream of LPA and other G- protein coupled-receptors $[28,41]$. This appears to involve the degradation of lipid phosphates formed downstream of receptor activation [42]. Consequently, targeted overexpression of LPP1 inside cells does attenuate LPA-induced activation of $\mathrm{Ca}^{2+}$-transients [30, 43]. In the case of human bronchial epithelial cells, this effect blocked the phosphorylation of I $\mathrm{I} B$ and translocation of NF- $\mathrm{kB}$ to the nucleus, which almost completely prevented IL-8 secretion [43]. However, this downstream effect on LPA receptor signaling was 


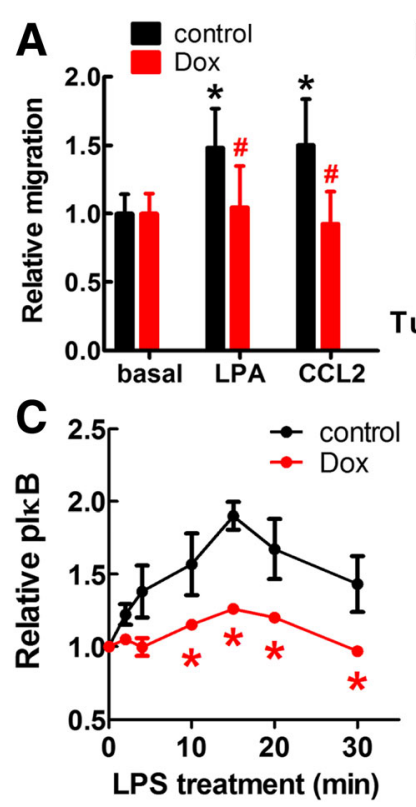

B

RAW264.7
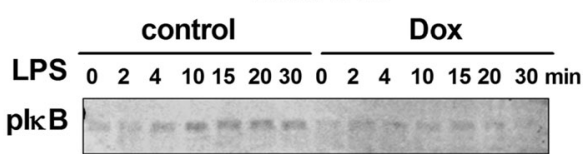

IKB $-m-m=m-m-m-m-n$

Tubulin
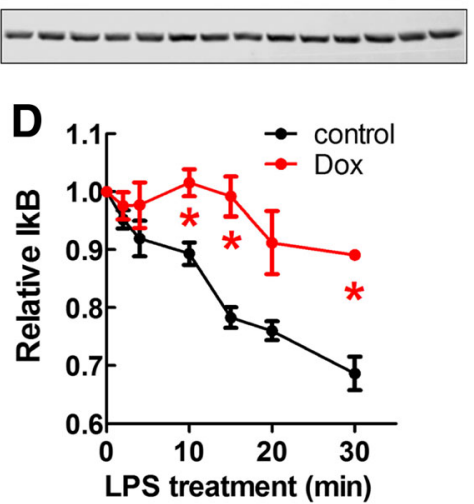

Fig. 6 Effects of Doxycycline on PBMCs and RAW264.7 cells. a. Dox at $5 \mu \mathrm{g} / \mathrm{ml}$ suppressed the migration of mouse PBMCs induced by $1 \mu \mathrm{M}$ of LPA and $100 \mathrm{ng} / \mathrm{ml}$ of CCL2. ${ }^{*} p<0.05$ relative to basal level, \# $p<0.05$ relative to control. $\mathbf{b}$. The effect of Dox on time course of phosphor-IKBa and total IkBa by $50 \mathrm{ng} / \mathrm{ml}$ of LPS in RAW264.7 cells. c. Quantification of phosphor-IkBa. d. Quantification of total IkBa. ${ }^{*} p<0.05$ relative to control. Results are means \pm SEM from three independent experiments. Results were analyzed by ANOVA with an SNK posthoc test
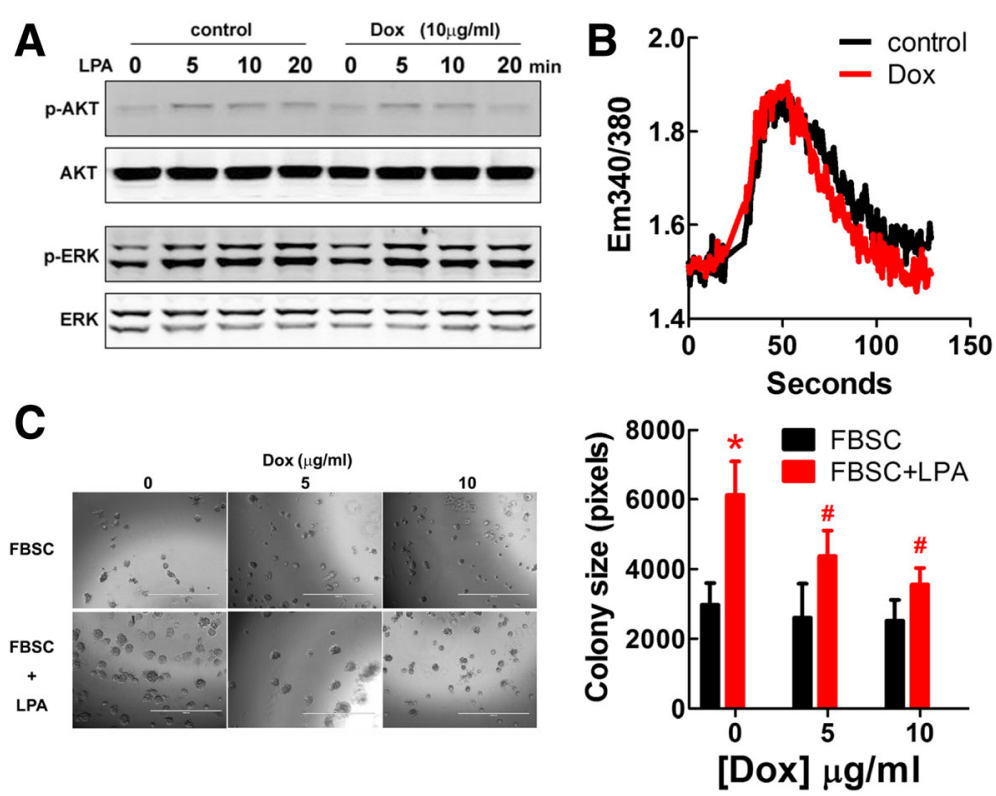

Fig. 7 Doxycycline (Dox) did not affect signal transduction by transient LPA stimulation, but attenuated the long term effect of LPA on cell growth. a. 4T1 cells were serum starved with DMEM/0.1\% BSA and stimulated with $1 \mu \mathrm{M}$ LPA for 5, 10 and 20 min. Dox at $10 \mu \mathrm{g} / \mathrm{ml}$ was included in serum starvation and stimulation. LPA-induced stimulations of Akt and ERK phosphorylations were not affected by Dox. b. MDA-MB-231 cells were serum starved with DMEM/0.1\% BSA and stimulated with $10 \mu \mathrm{M} \mathrm{LPA}$. Dox at $10 \mu \mathrm{g} / \mathrm{ml}$ was included in serum starvation. LPA-induced Ca ${ }^{2}$ ${ }^{+}$-mobilization was not affected by Dox. c. A three-dimensional culture system was established by layering $400 \mu \mathrm{l}$ of $4 \mathrm{~T} 1$ cell suspension (6000 cells in DMEM with 10\% FBSC and 2\% Matrige $\mathrm{I}^{\mathrm{TM} M}$ ) over $150 \mu \mathrm{l}$ Matrige $\mathrm{I}^{\mathrm{TM}}$ in an 8-well chamber with daily replacement with fresh medium containing LPA or drugs. Dox decreased the stimulation of 4T1 cell colony formation by $5 \mu \mathrm{M} \mathrm{LPA}$ after incubation for 9 days. Scale bar $=1000 \mu \mathrm{m}$. ${ }^{*} p<0.05$ relative to cells without Dox and LPA treatment, \# $p<0.05$ relative to cells treated with LPA but not Dox. Results are means \pm SEM from three independent experiments. Results were analyzed by ANOVA with an SNK posthoc test 
not involved in the doxycycline effect on LPP expression, which is increased LPP expression on the plasma membrane and thus decreased external LPA concentrations.

$\mathrm{NF}-\mathrm{KB}$ activation is stimulated by different receptors, e.g., the toll like receptor family, the TNF receptor super family and G protein-coupled receptors, including LPA receptors [44]. The signals are transmitted through different pathways depending on the type of receptor activated, but they converge on IkB kinase (IKK) [45]. IKK phosphorylates $\mathrm{I} \kappa \mathrm{B}$, an NF- $\mathrm{KB}$ inhibitor that prevents the translocation of NF- $\mathrm{KB}$ to the nuclear by binding to it in a dephosphorylated state. Upon phosphorylation, $I_{\kappa} B$ is degraded through ubiquitination and this releases $N F-k B$ from the sequestration. NF- $k B$ then enters the nuclear and mediates the expression of genes for inflammatory cytokines [45]. Our study showed that doxycycline suppressed both LPA- and TNF $\alpha$-induced nuclear translocation of NF- $\mathrm{KB}$ and blocked the LPA-induced secretion of IL-6, CCL2 and CXCL2 in cancer cells. TNF $\alpha$-induced nuclear NF- $\mathrm{B}$ transcriptional activity was also inhibited by doxycycline. Under basal condition without stimulation, doxycycline was able to decrease the transcriptional activity of nuclear NF-kB by $\sim 50 \%$, which explained the decreased IL- 6 mRNA and secretion of IL-6, CCL2 and CXCL2 by doxycycline when LPA and TNFa were absent. However, the nuclear translocation of NF- $\mathrm{KB}$ and I $\mathrm{KB}$ phosphorylation were not affected significantly by doxycycline under this basal condition. Although NF-kB nuclear translocation is an important step in $N F K B$ activation, modification of nuclear NF- $\mathrm{kB}$ by various events including phosphorylation, ubiquitination, nitrosylation, acetylation and interaction with different co-activators can affect its activity [46, 47]. Therefore, doxycycline inhibited the transcriptional activity of nuclear NF- $\mathrm{kB}$, but did not affect nuclear translocation of NF- $\mathrm{kB}$ under basal condition. Upon stimulation, doxycycline was able to inhibit both the induced NF- $\mathrm{kB}$ translocation and transcriptional activity. These results establish that doxycycline inhibited NF-KB-mediated transcription independently of signaling by LPA. Therefore, the anti-inflammatory activity of doxycycline consists of at least two components: 1) A decrease in the availability of LPA for stimulating inflammation and 2) Inhibition of NF- $k B$ activation that also decreases the production of inflammatory cytokines.

The chronic inflammatory milieu inside tumors polarizes TAMs to promote tumor growth [17-19]. For example, TAMs secrete growth factors including EGF [22], PDGF [23] and VEGF [24] to promote cancer cell proliferation and blood vessel formation. TAMs also inhibit the immune reaction of $\mathrm{CD}^{+} \mathrm{T}$-cells against cancer cells by producing IL-10 and TGF $\beta$ [26]. In our work, doxycycline not only suppressed the cancer cell-derived chemo-attractants for monocytes, e.g., IL-6 and CCL2, but also directly impaired the migration activity of mouse PBMCs. These actions on both cancer cells and monocytes were compatible with the $\sim 50 \%$ decrease of macrophage infiltration in the tumor. Furthermore, doxycycline blocked IкB phosphorylation and degradation in RAW264.7 macrophage cells in response to LPS, suggesting that the expressions of NF- $\mathrm{KB}$ target genes in TAMs were decreased. This could explain the different cytokine profile in the tumors after doxycycline treatment. Growth factors, e.g., G-CSF and VEGF, which are controlled by NF-kB $[48,49]$, were also decreased in the tumor by doxycycline. In many cancers, increased infiltration of tumors with TAMs is normally associated with a poor prognosis and the efficacy of targeting macrophages has been verified in preclinical studies for cancer therapy [50, 51]. The capability of doxycycline to selectively suppress TAM infiltration could maintain the anti-tumoral effects of $\mathrm{CD} 8^{+}$cytotoxic T-cells.

The effects of doxycycline that we reported in mice were obtained at a dose of $50 \mathrm{mg} / \mathrm{kg} /$ day. The equivalent dose for human is $\sim 4 \mathrm{mg} / \mathrm{kg} /$ day calculated by equivalent surface area dosage conversion factor, which is $240 \mathrm{mg} /$ day for $60 \mathrm{~kg}$ of body weight. The typical dose of doxycycline is $100-200 \mathrm{mg} /$ day and the maximum dose is $300 \mathrm{mg} /$ day for more serious infections, such as syphilis. Therefore, the dose of doxycycline used in this study is within the therapeutic range, which is used clinically.

\section{Conclusion}

The present work established the importance of a novel dimension of tetracycline action. Doxycycline is a relatively inexpensive, commonly used and welltolerated compound, which has multiple functions in addition to its anti-microbial activity. It is well known that tetracyclines inhibit matrix metalloproteinase activities [52]. These enzymes degrade extracellular matrix and this is involved in cancer cell invasion and migration. Several reports showed that tetracyclines have anti-neoplastic activity [51, 53, 54], but the mechanisms for this are poorly understood. This paper, together with our previous work [31], demonstrates a novel effect of tetracyclines in decreasing extracellular LPA concentrations by increasing the "ecto-activity" of the LPPs. This effect could be important for the treatment of cancers and other inflammatory conditions since LPA is an important regulator of inflammation through activation of NF-KB. In addition, doxycycline had a further action in decreasing NF- $\mathrm{KB}$ activation independently of the LPA signal. These combined actions of doxycycline make it a potential candidate for an adjuvant therapy for cancer and other inflammatory diseases. 


\section{Methods}

\section{Reagents and cell lines}

Oleoyl-LPA (233019) was from Avanti Polar Lipids (Alabaster, AL). Doxycyclinehyclate (0219895525) was from MP Biomedicals (Solon, OH). Fatty acid-free albumin from bovine serum (A8806), mouse anti tubulin (T6074) antibody, probenecid (P8761), Calcein AM (C1359), OptiPrep ${ }^{\text {тм }}$ density gradient medium (D1556), lipopolysaccharides (L3012) and protease inhibitor cocktail (P8340) were from Sigma (St. Louis, MO). Rabbit anti CD45 (ab10558), rabbit anti Foxp3 (ab54501), rabbit anti CD31 (ab28364), Alexa Fluor 488 conjugated anti rabbit IgG (ab150077) and HRP conjugated anti rat IgG (ab6734) antibodies were from Abcam (Toronto, ON, Canada); Rat anti F4/80 (14-4801), rat anti CD8 $\alpha$ (14-0808) antibodies were from eBioscience (San Diego, CA); mouse anti phospho-Akt (4051), rabbit anti Akt (4691), mouse anti phospho-ERK (9106), rabbit anti ERK (9102), mouse anti IкB (4814), rabbit anti phosphor-IкB (Ser32) (2859), rabbit anti Ki-67 (D3B5) and rabbit anti NF-kBp65 (8242) antibodies were from Cell Signaling Technology (Danvers, MA); Rabbit anti Lamin A/C (sc-20681) was from Santa Cruz (Dallas, TX). Fura-2 AM (F-1201) and F127 (P-6867) were from Life Technologies (Grand Island, NY). HRP conjugated anti rabbit IgG antibody and DAB was from DAKO (Carpinteria, CA). Matrigel ${ }^{\mathrm{TM}}(354230 / 354234)$ was from Corning (Corning, NY). Recombinant human TNF $\alpha$ (Z100857), recombinant mouse TNF $\alpha$ (Z200217), reverse transcription master mix (G490) and EvaGreen qPCR master mix (MasterMix-ER) were from Applied Biological Materials Inc. (Richmond, BC, Canada). Human mammary carcinoma cell lines MDA-MB-231, mouse mammary carcinoma cell line 4T1, mouse macrophage cell line RAW264.7, and HEK (human embryonic kidney) 293 cells were from ATCC (Manassas, VA). Cells were cultured in Dulbecco's Modified Eagle Medium (DMEM) with 10\% FBS.

\section{Real-time PCR and western blotting}

IL-6 mRNA levels were determined by qRT-PCR using glyceraldehyde 3-phosphate dehydrogenase (GAPDH) and cyclophilin A (CycA) as reference mRNA. Protein levels were measured by Western blotting as described previously [30]. Immunoblots were analyzed by Odyssey infrared imaging system (LI-COR Biosciences, NE).

\section{Intracellular $\mathrm{Ca}^{2+}$-mobilization assay}

MDA-MB-231 cells were serum starved overnight and detached by PBS containing $2 \mathrm{mM}$ EDTA and $0.1 \%(\mathrm{w} / \mathrm{v})$ fatty acid-free BSA, $\mathrm{pH}$ 7.4. Cells were washed and resuspended in $\mathrm{Ca}^{2+}$-, $\mathrm{Mg}^{2+}$ - and phenol red-free Hank's buffer containing $2.5 \mathrm{mM}$ probenecid and $0.1 \%(\mathrm{w} / \mathrm{v})$ fatty acidfree BSA. Cells were labeled with $2 \mathrm{mM}$ Fura-2 AM plus $0.02 \%(\mathrm{w} / \mathrm{v}) \mathrm{F} 127$, and incubated in the dark at $20{ }^{\circ} \mathrm{C}$ for
$40 \mathrm{~min}$. Following washing, cells were resuspended in the same buffer at $5 \times 10^{5}$ cells $/ \mathrm{ml}$, and $2 \mathrm{ml}$ of cell suspension was loaded into a quartz cuvette for fluorescence measurement using a fluorometer (C43/2000, PTI, NJ). LPA at $10 \mu \mathrm{M}$ was used for stimulation. The ratio of emission intensity at $510 \mathrm{~nm}$ that was caused by 340 and $380 \mathrm{~nm}$ excitation was used to calculate $\mathrm{Ca}^{2+}$-mobilization.

\section{NF-KB translocation assay}

MDA-MB-231 and 4T1 cells were cultured in $10-\mathrm{cm}$ dishes and serum starved over night when reach $80 \%$ confluent. Doxycycline was added together with the starvation medium. Cells were stimulated on the next day with $5 \mu \mathrm{M}$ of LPA or $20 \mathrm{ng} / \mathrm{ml}$ of TNF $\alpha$ for $0.5,1$ and $2 \mathrm{~h}$. Cells were washed twice with ice-cold PBS followed by adding $0.5 \mathrm{ml}$ of lysis buffer: $10 \mathrm{mM}$ HEPES; $\mathrm{pH} 7.5$, $10 \mathrm{mM} \mathrm{KCl}, 0.1 \mathrm{mM}$ EDTA, $1 \mathrm{mM}$ dithiothreitol (DTT), $0.5 \%$ Nonidet-40 and protease inhibitors. Cells were collected by scraping and kept on ice for $30 \mathrm{~min}$. After centrifuge at $12,000 \mathrm{~g}$ for $10 \mathrm{~min}$, the supernatants were collected as a cytoplasmic fraction and the nuclear pellets were washed with lysis buffer for 3 times, and then resuspended in nuclear extraction buffer containing 20 mM HEPES (pH 7.5), $400 \mathrm{mM} \mathrm{NaCl}, 1$ mM EDTA, $1 \mathrm{mM}$ DTT and protease inhibitors and incubated on ice for $30 \mathrm{~min}$. The supernatant was collected by centrifugation at $12,000 \mathrm{~g}$ for $15 \mathrm{~min}$ at $4{ }^{\circ} \mathrm{C}$ as nuclear extract. The level of NF- $\mathrm{KB}$ was determined by western blotting.

\section{Cell proliferation assay in three-dimensional culture}

$4 \mathrm{~T} 1$ cells were suspended in DMEM $\left(1.5 \times 10^{4}\right.$ cells $\left./ \mathrm{ml}\right)$ supplemented with $2 \%(\mathrm{v} / \mathrm{v})$ growth factor-reduced Matrigel $^{\mathrm{TM}}$ and 10\% FBSC. Cell suspension $(400 \mu \mathrm{l} /$ well $)$ was put onto the top of a thin layer of Matrigel $^{\mathrm{TM}}$ (150 $\mu \mathrm{l} /$ well) in 8-well chamber slides (177402, Thermo Scientific, Burlington, ON, Canada). LPA at $5 \mu \mathrm{M}$ and doxycycline at $5 \mu \mathrm{g} / \mathrm{ml}$ or $10 \mu \mathrm{g} / \mathrm{ml}$ were applied. Cells were grown for 9 days with daily replacement with fresh medium containing LPA and drugs, and fixed with $4 \%$ $(\mathrm{w} / \mathrm{v})$ paraformaldehyde. Phase-contrast images were acquired using an AMG EVOS digital inverted microscope (Electron Microscopy Sciences, PA). The average size of cell colonies was measured by ImageJ software.

\section{Mouse tumor model}

A syngeneic orthotopic mouse breast cancer model was established using 4T1 cells as previously reported [30]. All procedures were performed in accordance with the Canadian Council of Animal Care as approved by the University of Alberta Animal Welfare Committee. Female BALB/c mice were given doxycycline $50 \mathrm{mg} / \mathrm{kg} /$ day by i.p. injection. Control mice were given saline by i.p. injection. Tumor growth was monitored by two orthogonal caliper measurements and tumor volume was 
estimated from width ${ }^{2} \times$ length/2. After sacrificing the mice, blood and tumors were collected. Lungs were fixed with $10 \%$ formalin and then stained with India ink. Nodules on the surface were counted.

\section{Immunohistochemistry}

Tumors were fixed with $10 \%$ formalin followed with paraffin embedding and sectioning. Sample treatment and immuno-staining were performed according to the standard procedure. For $\mathrm{F} 4 / 80$ staining, $0.05 \%$ trypsin treatment at $37^{\circ} \mathrm{C}$ for $10 \mathrm{~min}$ was applied for antigen retrieval. For other antibodies, heating with Tris/EDTA, pH 9.0 in a pressure cooker was used for antigen retrieval. Positive staining events for CD45, CD8a, F4/80, Foxp3 and CD31 were selected and counted by ImageJ software. The average counts in 5 fields were calculated for each sample.

\section{Measurement of plasma LPA concentrations}

Mouse blood was collected by cardiac puncture using an EDTA coated syringe. Plasma LPA concentration was measured as described previously [27]. Blood samples were centrifuged at $14,000 \mathrm{rpm}$ for $1 \mathrm{~min}$ and plasma was collected. Plasma was treated with isotope labeled C17:0-LPA as internal standards and lipid phosphates were extracted into butan-1-ol. Lysophospholipids were measured by LC/MS with electrospray ionization in the negative ion mode using an Agilent 1200 series LC system coupled to a 3200 QTRAP mass spectrometer (AB Sciex, Concord, ON, Canada). The concentrations of different LPA species (C16:0-LPA, C20:4-LPA, C18:0-LPA and C18:1-LPA) were summed as total LPA concentration in plasma.

\section{Measurement of ATX activity}

ATX activity was measured in $50 \mu \mathrm{l}$ by the choline released from lysophosphatidylcholine (LPC) as previous reported [27]. Ten $\mu \mathrm{l}$ of plasma was mixed with $15 \mu \mathrm{l}$ of buffer A $(100 \mathrm{mM}$ Tris- $\mathrm{HCl}, \mathrm{pH}$ 9.0; $500 \mathrm{mM} \mathrm{NaCl}$; $500 \mathrm{mM} \mathrm{MgCl} 2$; and $0.05 \% \mathrm{v} / \mathrm{v}$ Triton X-100) and preincubated at $37{ }^{\circ} \mathrm{C}$ for $30 \mathrm{~min}$. Samples were then mixed with $25 \mu \mathrm{l}$ of $6 \mathrm{mM} \mathrm{C14:0-LPC}$ in buffer A and incubated for $6 \mathrm{~h}$ at $37^{\circ} \mathrm{C}$ when $20 \mu \mathrm{l}$ samples were pipetted in duplicate into a 96-well plate and incubated at $37{ }^{\circ} \mathrm{C}$ for $20 \mathrm{~min}$ with $90 \mu \mathrm{l} /$ well of buffer $\mathrm{C}[9.65 \mathrm{ml}$ buffer B $\left(100 \mathrm{mM}\right.$ Tris- $\mathrm{HCl}, \mathrm{pH} 8.5$, and $5 \mathrm{mM} \mathrm{CaCl}_{2}$ ), $110 \mu \mathrm{l}$ of $30 \mathrm{mM}$ TOOS ( $N$-ethyl- $N$-(2-hydroxy-3-sulfopropyl)-3methylaniline, sodium salt, dehydrate; Dojindo Molecular Technologies, Rockville, MD, USA), $110 \mu \mathrm{l}$ of $50 \mathrm{mM}$ 4-aminotipyrine, $6.6 \mu \mathrm{l}$ of $1000 \mathrm{U} / \mathrm{ml}$ horseradish peroxidase, and $110 \mu \mathrm{l}$ of $300 \mathrm{U} / \mathrm{ml}$ choline oxidase]. Choline formation was measured at $550 \mathrm{~nm}$. Activity measurements were normalized to protein content.

\section{Multiplex cytokine/chemokine measurements}

Cytokines, chemokines, and growth factors were analyzed by Eve Technologies Corp. (Calgary, AB, Canada), with a Milliplex Mouse Cytokine/Chemokine 32-plex kit (Millipore, MO), according to the manufacturer's protocol, on a Luminex 100 system (Luminex, Austin, TX). Tissue specimens (10-25 $\mathrm{mg}$ ) were homogenized in $200 \mu \mathrm{l}$ of $20 \mathrm{mM}$ Tris- $\mathrm{HCl}(\mathrm{pH}$ 7.5) buffer with $0.5 \%$ Tween 20, $150 \mathrm{mM} \mathrm{NaCl}$, and protease inhibitors and centrifuged for $10 \mathrm{~min}$ at $4{ }^{\circ} \mathrm{C}$, and the supernatant was transferred to a fresh tube. Protein content was measured using the bicinchoninic acid protein assay (Thermo Fisher Scientific; IL). For supernatant analysis, conditioned media were centrifuged before multiplex analysis. Measurements were normalized to the cell protein. Plasma samples were diluted with an equal volume of PBS before analysis.

\section{Separation of mouse PBMCs and the transwell migration assay}

Blood was collected by cardiac puncture in EDTA-coated tubes from 10 mice. Blood was diluted at 1:1 (v/v) with tricine-buffered saline (TBS): $0.85 \% \mathrm{NaCl}, 10 \mathrm{mM}$ Tricine$\mathrm{NaOH}, \mathrm{pH} 7.0$. A density barrier was prepared by mixing OptiPrep $^{\text {tm }}$ with TBS and water at volume ratio of 45:155:31 respectively. One $\mathrm{ml}$ of the density barrier was added in a $15-\mathrm{ml}$ centrifuge tube followed by adding $2 \mathrm{ml}$ of diluted blood on the top of it. Tubes were centrifuged at $700 \mathrm{~g}$ for $20 \mathrm{~min}$ at $20{ }^{\circ} \mathrm{C}$. The PBMC band was collected at the interface. Contaminating red blood cells were removed using a red blood cell lysis buffer consisting of: $155 \mathrm{mM}$ $\mathrm{NH}_{4} \mathrm{Cl}, 10 \mathrm{mM} \mathrm{KHCO}_{3}, 0.1 \mathrm{mM}$ EDTA, $\mathrm{pH}$ 7.3. The PBMC pellet was washed twice with RPMI medium. PBMCs were cultured in RPMI with $0.1 \%$ BSA. Cells were pre-treated with $5 \mu \mathrm{g} / \mathrm{ml}$ doxycycline for $12 \mathrm{~h}$ before the experiment. PBMCs were labeled with $5 \mu \mathrm{M}$ calcein-AM at $37{ }^{\circ} \mathrm{C}$ for $30 \mathrm{~min}$. Cells were washed 3 times with RPMI and resuspended in RPMI with $0.1 \%$ BSA at $5 \times 10^{6}$ cells $/ \mathrm{ml}$. The transwell assay was performed using a 96-well Boyden chamber as reported previously [30]. LPA at $1 \mu \mathrm{M}$ or CCL2 at $100 \mathrm{ng} / \mathrm{ml}$ were added in the lower chambers and $100 \mu \mathrm{l}$ of cell suspension was added into the upper chamber. The chambers were incubated at $37{ }^{\circ} \mathrm{C}$ in a tissue culture incubator for $90 \mathrm{~min}$. Cells that migrated into the lower chamber were quantified with a plate reader (Fluoroskan Ascent, ThermoFisher Scientific, Burlington, ON, Canada) at Ex488/Em510.

\section{Statistical analysis}

Results were analyzed by Student's $t$-test or by ANOVA for multiple comparisons followed by Student-Newman-Keuls (SNK) test. $p<0.05$ was considered statistically significant. 


\section{Additional files}

Additional file 1: Effects of doxycycline (Dox) on tumor growth, metastasis, and leukocyteinfiltration. (PPTX $2548 \mathrm{~kb}$ )

Additional file 2: Cytokine levels in plasma of the BALB/C mice with tumor. (PPTX $274 \mathrm{~kb}$ )

Additional file 3: Effects of doxycycline (Dox) on NF-kB activity. (PPTX $102 \mathrm{~kb}$ )

Additional file 4: Effects of Doxycycline (Dox) on Ki-67 expression. (PPTX $706 \mathrm{~kb}$ )

\section{Abbreviations}

ATX: Autotaxin; CCL: Chemokine (C-C motif) ligand; CXCL: Chemokine (C-X-C motif) ligand; G-CSF: Granulocyte colony-stimulating factor; IL: Interleukin; LIF: Leukemia inhibitory factor; LPA: Lysophosphatidic acid, which at physiological pH is in a salt form, lysophosphatidate; LPP: Lipid phosphate phosphatase; LPS: Lipopolysaccharide; PBMC: Peripheral blood mononuclear cells; TAM: Tumor-associated macrophages; VEGF: Vascular endothelial growth factor

\section{Acknowledgments}

XW received salary support from the Department of Pathology, Qiqihar Medical University, China. XT held a research fellowship from the Canadian Breast Cancer Foundation.

\section{Funding}

The work was supported by the Canadian Breast Cancer Foundation and by an innovation grant from the Canadian Cancer Society Research Institute.

\section{Availability of data and materials}

Additional data are available as supplementary figures.

\section{Authors' contributions}

XT carried out the animal experiments, molecular biology studies, performed the statistical analysis and drafted the manuscript. XW carried out the tissue culture and molecular biology studies. YZ carried out the LC/MS assay. DB and JC participated in the design of the study and helped to draft the manuscript. All authors read and approved the final manuscript.

\section{Competing interests}

The authors declare that they have no competing interests.

\section{Consent for publication}

Not applicable.

\section{Ethics approval and consent to participate}

Animal experiment was performed in accordance with the Canadian Council of Animal Care as approved by the University of Alberta Animal Welfare Committee.

\section{Author details}

${ }^{1}$ Department of Biochemistry, Signal Transduction Research Group, University of Alberta, Edmonton, AB T6G 2S2, Canada. Department of Agricultural, Food and Nutritional Science, University of Alberta, 410 Agriculture/Forestry Centre, 3-60D South Academic Building, Edmonton, AB T6G 2P5, Canada. ${ }^{3}$ Department of Biochemistry, 357 Heritage Medical Research Centre, University of Alberta, Edmonton, AB T6G 2S2, Canada.

Received: 30 August 2016 Accepted: 30 January 2017 Published online: 08 February 2017

\section{References}

1. Colotta F, Allavena P, Sica A, Garlanda C, Mantovani A. Cancer-related inflammation, the seventh hallmark of cancer: links to genetic instability. Carcinogenesis. 2009;30:1073-81.

2. Candido J, Hagemann T. Cancer-related inflammation. J Clin Immunol. 2013; 33 Suppl 1:S79-84

3. Mantovani A, Allavena P, Sica A, Balkwill F. Cancer-related inflammation. Nature. 2008;454:436-44.
4. Brindley DN, Lin FT, Tigyi GJ. Role of the autotaxin-lysophosphatidate axis in cancer resistance to chemotherapy and radiotherapy. Biochim Biophys Acta. 1831;2013:74-85.

5. Benesch MG, Ko YM, McMullen TP, Brindley DN. Autotaxin in the crosshairs: taking aim at cancer and other inflammatory conditions. FEBS Lett. 2014; 588:2712-27.

6. Samadi N, Bekele R, Capatos D, Venkatraman G, Sariahmetoglu M, Brindley DN. Regulation of lysophosphatidate signaling by autotaxin and lipid phosphate phosphatases with respect to tumor progression, angiogenesis, metastasis and chemo-resistance. Biochimie. 2011;93:61-70.

7. Liu S, Umezu-Goto M, Murph M, Lu Y, Liu W, Zhang F, Yu S, Stephens LC, Cui $X$, Murrow G, et al. Expression of autotaxin and lysophosphatidic acid receptors increases mammary tumorigenesis, invasion, and metastases. Cancer Cell. 2009;15:539-50.

8. So J, Wang FQ, Navari J, Schreher J, Fishman DA. LPA-induced epithelial ovarian cancer (EOC) in vitro invasion and migration are mediated by VEGF receptor-2 (VEGF-R2). Gynecol Oncol. 2005;97:870-8.

9. Murph MM, Hurst-Kennedy J, Newton V, Brindley DN, Radhakrishna H. Lysophosphatidic acid decreases the nuclear localization and cellular abundance of the p53 tumor suppressor in A549 lung carcinoma cells. Mol Cancer Res. 2007:5:1201-11.

10. Benesch MG, Ko YM, Tang X, Dewald J, Lopez-Campistrous A, Zhao YY, Lai R, Curtis JM, Brindley DN, McMullen TP. Autotaxin is an inflammatory mediator and therapeutic target in thyroid cancer. Endocr Relat Cancer. 2015;22:593-607.

11. Benesch MG, Tang X, Dewald J, Dong WF, Mackey JR, Hemmings DG, McMullen TP, Brindley DN. Tumor-induced inflammation in mammary adipose tissue stimulates a vicious cycle of autotaxin expression and breast cancer progression. FASEB J. 2015;29:3990-4000.

12. Nakasaki T, Tanaka T, Okudaira S, Hirosawa M, Umemoto E, Otani K, Jin S, Ba Z, Hayasaka H, Fukui Y, et al. Involvement of the lysophosphatidic acidgenerating enzyme autotaxin in lymphocyte-endothelial cell interactions. Am J Pathol. 2008;173:1566-76.

13. van Meeteren LA, Moolenaar WH. Regulation and biological activities of the autotaxin-LPA axis. Prog Lipid Res. 2007:46:145-60.

14. Boutin JA, Ferry G. Autotaxin. Cell Mol Life Sci. 2009;66:3009-21.

15. Chou CH, Wei LH, Kuo ML, Huang YJ, Lai KP, Chen CA, Hsieh CY. Upregulation of interleukin-6 in human ovarian cancer cell via a Gi/PI3K-Akt/ NF-kappaB pathway by lysophosphatidic acid, an ovarian cancer-activating factor. Carcinogenesis. 2005;26:45-52.

16. Venkatraman G, Benesch MG, Tang X, Dewald J, McMullen TP, Brindley DN. Lysophosphatidate signaling stabilizes Nrf2 and increases the expression of genes involved in drug resistance and oxidative stress responses: implications for cancer treatment. FASEB J. 2015;29:772-85.

17. Nabeshima A, Matsumoto Y, Fukushi J, lura K, Matsunobu T, Endo M, Fujiwara T, lida K, Fujiwara Y, Hatano M, et al. Tumour-associated macrophages correlate with poor prognosis in myxoid liposarcoma and promote cell motility and invasion via the HB-EGF-EGFR-PI3K/Akt pathways. Br J Cancer. 2015;112:547-55

18. Zhang QW, Liu L, Gong CY, Shi HS, Zeng YH, Wang XZ, Zhao YW, Wei YQ. Prognostic significance of tumor-associated macrophages in solid tumor: a meta-analysis of the literature. PLoS One. 2012;7:e50946.

19. Gwak JM, Jang MH, Kim DI, Seo AN, Park SY. Prognostic value of tumorassociated macrophages according to histologic locations and hormone receptor status in breast cancer. PLoS One. 2015;10:e0125728.

20. Williams CB, Yeh ES, Soloff AC. Tumor-associated macrophages: unwitting accomplices in breast cancer malignancy. NPJ Breast Cancer. 2016;2:15025.

21. Li X, Yao W, Yuan Y, Chen P, Li B, Li J, Chu R, Song H, Xie D, Jiang X, Wang $\mathrm{H}$. Targeting of tumour-infiltrating macrophages via CCL2/CCR2 signalling as a therapeutic strategy against hepatocellular carcinoma. Gut. 2017;66: 157-67.

22. Wyckoff J, Wang W, Lin EY, Wang Y, Pixley F, Stanley ER, Graf T, Pollard JW Segall J, Condeelis J. A paracrine loop between tumor cells and macrophages is required for tumor cell migration in mammary tumors. Cancer Res. 2004:64:7022-9.

23. Vignaud JM, Marie B, Klein N, Plenat F, Pech M, Borrelly J, Martinet N, Duprez A, Martinet $Y$. The role of platelet-derived growth factor production by tumor-associated macrophages in tumor stroma formation in lung cancer. Cancer Res. 1994:54:5455-63.

24. Lewis JS, Landers RJ, Underwood JC, Harris AL, Lewis CE. Expression of vascular endothelial growth factor by macrophages is up-regulated in poorly vascularized areas of breast carcinomas. J Pathol. 2000;192:150-8. 
25. Wang R, Lu M, Zhang J, Chen S, Luo X, Qin Y, Chen H. Increased IL-10 mRNA expression in tumor-associated macrophage correlated with late stage of lung cancer. J Exp Clin Cancer Res. 2011;30:62.

26. Kataki A, Scheid P, Piet M, Marie B, Martinet N, Martinet Y, Vignaud JM. Tumor infiltrating lymphocytes and macrophages have a potential dual role in lung cancer by supporting both host-defense and tumor progression. J Lab Clin Med. 2002;140:320-8.

27. Benesch MG, Tang X, Maeda T, Ohhata A, Zhao YY, Kok BP, Dewald J, Hitt M, Curtis JM, McMullen TP, Brindley DN. Inhibition of autotaxin delays breast tumor growth and lung metastasis in mice. FASEB J. 2014;28:2655-66.

28. Tang X, Benesch MG, Brindley DN. Lipid phosphate phosphatases and their roles in mammalian physiology and pathology. J Lipid Res. 2015;56:2048-60.

29. Brindley DN, Pilquil C. Lipid phosphate phosphatases and signaling. J Lipid Res. 2009;50(Suppl):S225-30.

30. Tang $X$, Benesch MG, Dewald J, Zhao YY, Patwardhan N, Santos WL, Curtis JM, McMullen TP, Brindley DN. Lipid phosphate phosphatase-1 expression in cancer cells attenuates tumor growth and metastasis in mice. J Lipid Res. 2014;55:2389-400

31. Tang X, Zhao YY, Dewald J, Curtis JM, Brindley DN. Tetracyclines increase lipid phosphate phosphatase expression on plasma membranes and turnover of plasma lysophosphatidate. J Lipid Res. 2016:57:597-606.

32. Farrah $\mathrm{G}$, Tan $\mathrm{E}$. The use of oral antibiotics in treating acne vulgaris: a new approach. Dermatol Ther. 2016;29:377-84.

33. Di Nardo A, Holmes AD, Muto Y, Huang EY, Preston N, Winkelman WJ, Gallo RL. Improved clinical outcome and biomarkers in adults with papulopustular rosacea treated with doxycycline modified-release capsules in a randomized trial. J Am Acad Dermatol. 2016;74:1086-92.

34. Rosso JQ. Management of papulopustular rosacea and perioral dermatitis with emphasis on iatrogenic causation or exacerbation of inflammatory facial dermatoses: use of doxycycline-modified release $40 \mathrm{mg}$ capsule once daily in combination with properly selected skin care as an effective therapeutic approach. J Clin Aesthet Dermatol. 2011:4:20-30.

35. Golub LM, Lee HM, Stoner JA, Sorsa T, Reinhardt RA, Wolff MS, Ryan ME, Nummikoski PV, Payne JB. Subantimicrobial-dose doxycycline modulates gingival crevicular fluid biomarkers of periodontitis in postmenopausal osteopenic women. J Periodontol. 2008;79:1409-18.

36. Voils SA, Evans ME, Lane MT, Schosser RH, Rapp RP. Use of macrolides and tetracyclines for chronic inflammatory diseases. Ann Pharmacother. 2005;39: 86-94.

37. Smith Jr GN, Yu Jr LP, Brandt KD, Capello WN. Oral administration of doxycycline reduces collagenase and gelatinase activities in extracts of human osteoarthritic cartilage. J Rheumatol. 1998;25:532-5.

38. Wollina U. Subantimicrobial-dose doxycycline monohydrate in dermatology. Wien Med Wochenschr. 2015;165:499-503.

39. He L, Marneros AG. Doxycycline inhibits polarization of macrophages to the proangiogenic M2-type and subsequent neovascularization. J Biol Chem 2014;289:8019-28.

40. Benesch MG, Tang X, Venkatraman G, Bekele RT, Brindley DN. Recent advances in targeting the autotaxin-lysophosphatidate-lipid phosphate phosphatase axis in vivo. J Biomed Res. 2016;30:272-84.

41. Alderton F, Darroch P, Sambi B, McKie A, Ahmed IS, Pyne N, Pyne S. G-proteincoupled receptor stimulation of the p42/p44 mitogen-activated protein kinase pathway is attenuated by lipid phosphate phosphatases 1, 1a, and 2 in human embryonic kidney 293 cells. J Biol Chem. 2001;276:13452-60.

42. Kok BP, Venkatraman G, Capatos D, Brindley DN. Unlike two peas in a pod: lipid phosphate phosphatases and phosphatidate phosphatases. Chem Rev. 2012;112:5121-46.

43. Zhao Y, Usatyuk PV, Cummings R, Saatian B, He D, Watkins T, Morris A, Spannhake EW, Brindley DN, Natarajan V. Lipid phosphate phosphatase-1 regulates lysophosphatidic acid-induced calcium release, NF-kappaB activation and interleukin-8 secretion in human bronchial epithelial cells. Biochem J. 2005;385:493-502

44. Mitchell S, Vargas J, Hoffmann A. Signaling via the NFkappaB system. Wiley Interdiscip Rev Syst Biol Med. 2016:8:227-41.

45. Wang W, Nag SA, Zhang R. Targeting the NFkappaB signaling pathways for breast cancer prevention and therapy. Curr Med Chem. 2015;22:264-89.

46. Ea CK, Baltimore D. Regulation of NF-kappaB activity through lysine monomethylation of p65. Proc Natl Acad Sci U S A. 2009;106:18972-7.

47. Perkins ND. Post-translational modifications regulating the activity and function of the nuclear factor kappa B pathway. Oncogene. 2006;25:6717-30.
48. Nishizawa M, Nagata S. Regulatory elements responsible for inducible expression of the granulocyte colony-stimulating factor gene in macrophages. Mol Cell Biol. 1990;10:2002-11.

49. Chilov D, Kukk E, Taira S, Jeltsch M, Kaukonen J, Palotie A, Joukov V, Alitalo K. Genomic organization of human and mouse genes for vascular endothelial growth factor C. J Biol Chem. 1997;272:25176-83.

50. Griesmann H, Drexel C, Milosevic N, Sipos B, Rosendahl J, Gress TM, Michl P. Pharmacological macrophage inhibition decreases metastasis formation in a genetic model of pancreatic cancer. Gut. 2016; doi:10.1136/gutjnl-2015310049.

51. Zhang C, Gao L, Cai Y, Liu H, Gao D, Lai J, Jia B, Wang F, Liu Z. Inhibition of tumor growth and metastasis by photoimmunotherapy targeting tumorassociated macrophage in a sorafenib-resistant tumor model. Biomaterials. 2016;84:1-12.

52. Myers SA, Wolowacz RG. Tetracycline-based MMP inhibitors can prevent fibroblastmediated collagen gel contraction in vitro. Adv Dent Res. 1998;12:86-93.

53. Wan L, Dong H, Xu H, Ma J, Zhu Y, Lu Y, Wang J, Zhang T, Li T, Xie J, et al. Aspirin, lysine, mifepristone and doxycycline combined can effectively and safely prevent and treat cancer metastasis: prevent seeds from gemmating on soil. Oncotarget. 2015;6:35157-72.

54. Pulvino M, Chen L, Oleksyn D, Li J, Compitello G, Rossi R, Spence S, Balakrishnan V, Jordan C, Poligone B, et al. Inhibition of COP9-signalosome (CSN) deneddylating activity and tumor growth of diffuse large B-cell lymphomas by doxycycline. Oncotarget. 2015;6:14796-813.

\section{Submit your next manuscript to BioMed Central and we will help you at every step:}

- We accept pre-submission inquiries

- Our selector tool helps you to find the most relevant journal

- We provide round the clock customer support

- Convenient online submission

- Thorough peer review

- Inclusion in PubMed and all major indexing services

- Maximum visibility for your research

Submit your manuscript at www.biomedcentral.com/submit
) Biomed Central 